Railma Pereira Moraes ${ }^{1+}$, Warley Augusto Caldas Carvalho', José Aldo Alves Pereira', Gleisson Oliveira Nascimento², Dalmo Arantes Barros'

\title{
EFFECT OF TOPSOIL STOCKPILING ON THE VIABILITY OF SEED BANK IN FIELD PHYTOPHYSIOGNOMIES CAMPOS DE ALTITUDE
}

Keywords:

Seed longevity

Bauxite

Degraded areas

Mining

Herbaceous species

Historic:

Received 02/04/2017

Accepted 16/08/2017

Palavras chave:

Longevidade de sementes

Bauxita

Áreas degradadas

Mineração

Especies herbáceas

${ }^{+}$Correspondence: railmoraes@yahoo.com.br
ABSTRACT: The viability of propagules during topsoil stockpiling is a limiting factor in ecological restoration projects and little is known about the species distributed in the campos de altitude. This work was carried out to investigate the viability of propagules present in the topsoil under campos de altitude vegetation, stockpiled for up to 12 months after the stripping of areas to be mined. In the south of Minas Gerais, Brazil, between November 20II and November 20I2, four collections of the seed bank were carried out, considering three depths (0 to 10, 90 to 100 , and 190 to $200 \mathrm{~cm}$ ) of the plot of stockpiled topsoil. Using the multivariate analysis, it was verified that the depth factor does not statistically affect the abundance of emerged individuals, while the factor time of stockpiling negatively affects the viability of the seeds. Some species were affected by the stockpiling conditions, only emerging in some collections, while others (Achyrocline satureioides, Ageratum fastigiatum, Baccharis dracunculifolia, Borreria capitata, Echinolaena inflexa and Melinis minutiflora) had individuals emerged in all collection periods. This study points out the need for the return of the topsoil until the fourth month of stocking, under the risk of monodominance, with a prevalence of species more adapted to predominant conditions of campos de altitude.

\section{EFEITO DA ESTOCAGEM DE TOPSOIL NA VIABILIDADE DO BANCO DE SEMENTES EM FITOFISIONOMIAS DE CAMPOS DE ALTITUDE}

RESUMO: A viabilidade dos propágulos durante a estocagem de topsoil é um fator limitante em projetos de restauração ecológica, e pouco se sabe sobre as espécies distribuídas nos campos de altitude. Este trabalho foi realizado com o objetivo de investigar a viabilidade de propágulos presente no topsoil sob vegetação de campos de altitude, estocado por até 12 meses após o decapeamento de áreas a serem mineradas. Entre o período de novembro de $20 \mathrm{II}$ a novembro de 2012 foram realizadas quatro coletas do banco de sementes, sendo consideradas três profundidades $(0$ a 10,90 a 100 e 190 a $200 \mathrm{~cm}$ ) da leira de topsoil estocada. Utilizando a análise multivariada, verificou-se que o fator profundidade não afeta estatisticamente a abundância de indivíduos emergidos, enquanto o fator tempo de estocagem afeta negativamente a viabilidade das sementes. Algumas espécies foram afetadas pelas condições de estoque do topsoil, emergindo somente em algumas coletas, enquanto outras (Achyrocline satureioides, Ageratum fastigiatum, Baccharis dracunculifolia, Borreria capitata, Echinolaena inflexa e Melinis minutiflora) tiveram indivíduos emergidos em todos os períodos de coleta. Este estudo aponta a necessidade do retorno do topsoil até o quarto mês de armazenamento, sob o risco de ocorrer monodominância, com predominância de espécies mais adaptadas as condições campestres. 


\section{INTRODUCTION}

The campos de altitude are environments characterized as mountain tops of southern and southeastern Brazil (SAFFORD, 1999; COSTA et al., $20 \mathrm{II}$ ), with recognized biological, geological, and hydric importance (SAFFORD, 1999; SCHEER et al., 20II), belonging to the domain of the Atlantic Forest. They are characterized by their high ecological fragility, constituted by a rare Brazilian vegetation, with predominance of grasses, herbs, and some pteridophytes (SAFFORD, 1999; CAIAFA; SILVA, 2005; MOCOCHINSKI; SCHEER, 2008). Because they are small species with little commercial interest, most of them from the Asteraceae, Fabaceae, Cyperaceae, and Melastomataceae families (CAIAFA; SILVA, 2005; MOCOCHINSKI; SCHEER, 2008; MEIRELES et al., 20I4), the vegetation has been little studied and is among the most unknown (MOCOCHINSKI; SCHEER 2008; MORAS FILHO et al, 2017). It should be noted that these areas are not restricted to Brazil, occurring in regions with high altitudes, such as the "páramos" in the Andes (SAFFORD, 2007).

However, in view of the need to recover areas of altitude fields after mining activities (BRASIL, 1988; SÁNCHEZ, 20II), among other environmental degradation situations, it is necessary to investigate techniques to make environmental recovery plans more efficient. The use of topsoil (RIVERA et al., 20I2; GOLOS; DIXON, 20I4) is a widespread technique in revegetation activities after bauxite mining (Barros, 2013). The seed bank, contained in the stockpiled topsoil, has favorable implications for vegetation succession and restoration (FERREIRA et al., 2015; SHANGA et al., 2016). Nevertheless, the composition, richness, and density of species present in the soil seed bank are influenced by the storage environment (SNYMAN, 20I3; SANTOS et al., 2016), which may be a limiting factor for recovery activities in areas of recognized fragility in the floristic composition.

Seed production often occurs under a narrow range of environmental conditions (OTT; HARTNETT, 2015) and can be abundant in the seed bank only for a given period or year (SNYMAN, 2013). Seeds may also synchronize their germination and dormancy cycles to regular seasonal environmental changes (FENNER; THOMPSON, 2005; GARCIA et al., 20I4), increasing their longevity under local conditions (SNYMAN, 20I3). Le Stradic et al. (2015), studying 15 species of rupestrian fields, affirmed that the environment presents a great diversity of strategies for germination of its seeds, in which this difference can be seen among species and among families.

Seed bank storage conditions may reduce seeds viability (HU et al., 20I3, GOLOS; DIXON, 20I4) and lead to a new plant community, unlike the one that provided the material (VAN ETTEN et al., 2014). The current studies have focused the caracterization of environmental conditions that minimize the decline of seed bank viability (PAKEMAN et al., 2012; GOLOS; DIXON, 20I4; NASCIMENTO et al., 2016); however, it is necessary to understand the influence of factors intrinsic to the stockpile, such as stockpile height and vegetal composition in different periods, considering that the topsoil can be stored or partially used. (BARROS et al., 20I2). Thus, innovative surveys in altitude fields become important tools for the development of strategies of seed bank management (BORGY et al., 20I5), since these are highly variable or unpredictable environments, with few studies (BARROS et al., 20I3; FERREIRA et al., 20I5).

The objective of the present work was to evaluate the viability of the regenerating material present in the topsoil, analyzing the emergence of propagules during one year and in three depths in stocked plots at the time of stripping, before the mining activity.

\section{MATERIAL AND METHODS}

\section{Characterization of the study area}

The topsoil was collected in a bauxite mining area in the Plateau Region of Poços de Caldas, around $21^{\circ} 52^{\prime} 38^{\prime \prime} \mathrm{S}$ and $46^{\circ} 27^{\prime} 48^{\prime \prime} \mathrm{W}$. The region is inserted in the Atlantic Forest domain (IBGE, 20I2) mainly occupied by vegetation associated with Campos de altitude. The climate is mesothermic, Cwb type, according to Köppen classification (Moraes and Jiménez-Rueda, 2008), with a rainfall index of $1,706.00 \mathrm{~mm}$ and an average annual temperature of $17.7^{\circ} \mathrm{C}$ (OLIVEIRA-FILHO, 20I4). There are two well-defined seasons: a rainy season, which begins in September and goes through March, and a dry period, which begins in April and lasts until August (PEREIRA; FONTES, 2009). The average precipitation and minimum and maximum temperatures during the study period are presented in Figure I.

\section{Sampling procedure}

To evaluate the viability of stocked topsoil, the soil was sampled from three stocked piles, kept uncovered, downstream of the interference area of the mining activity after the stripping. There were four sample collections over a year (BASKIN; BASKIN, 20I4), in different seasons (MARTINS, 20I4). The collection of the stocked material started in November 20II, when stripping was performed with a bulldozer, and finished in November 2012 (Figure 2), with the use of topsoil in the mined area. 


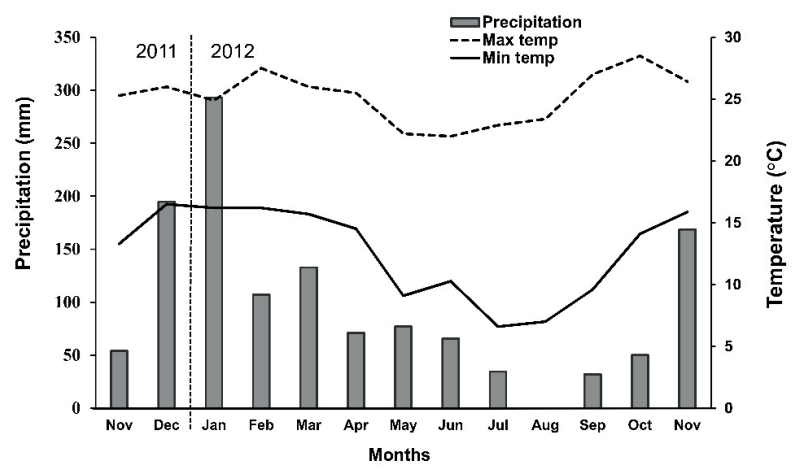

FIGURE I Climatic data of monthly precipitation and maximum and minimum temperature of the air in the Poços de Caldas plateau, Brazil. Source: Instituto Nacional de Meteorologia, 2016.

In each collection, three depths (0 to 10,90 to 100 , and 190 to $200 \mathrm{~cm}$ ) of soil were sampled, taken from the central area, and repeated in three different piles. A clamshell digger was used as the instrument of collection.

\section{Evaluations of the emergence of seedlings from stockpiled topsoil}

The collected material was taken to the forest nursery of the Federal University of Lavras and kept in a greenhouse, glass-covered to ensure high luminosity. For the tests, a $2-\mathrm{cm}$ layer of soil was spread over a $1.50-\mathrm{cm}$ bed of sterilized sand in an autoclave arranged in plastic trays. The seedlings that emerged were quantified and identified for the database.

The absolute density (individual $\cdot \mathrm{m}^{-2}$ ) was calculated considering the dimensions $33 \times 44 \mathrm{~cm}$, equivalent to each of the 36 trays. The diversity indexes were calculated according to the values found for species abundance present in the samples. Therefore, the Shannon $\left(H^{\prime}\right)$ and Pielou Equability (J') indices were calculated.

The matrices of similarities used were based on the Bray-Curtis index (Magurran, 1988). Differences of species abundance found in the seed bank in each collection were

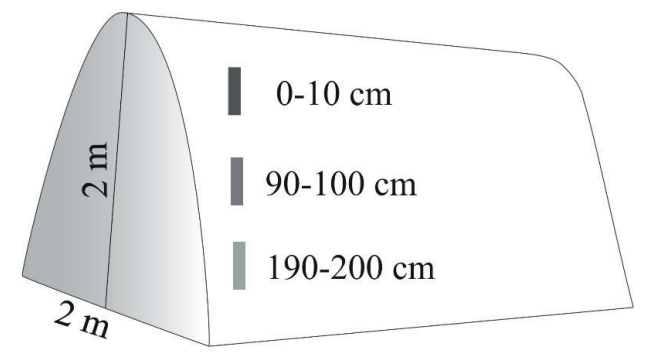

Nov. 2011 Mar. $2012 \quad$ Jul. $2012 \quad$ Nov. 2012

FIGURE 2 Sampling scheme of topsoil stocked during bauxite mining under altitude fields at three depths and four periods in the Poços de Caldas plateau region, MG. tested by a two-way PERMANOVA, with four periods and at three collection depths. A PERMDISP was also calculated to verify the homogeneity in the dispersion of the points in the multivariate space, and thus, find differences between the levels, considering the distance between the centroids (ANDERSON, 2006). These analyzes were performed by the statistical program PRIMER (version 6.0) with the PERMANOVA update package (CLARKE; GORLEY, 2006; ANDERSON et al., 2008).

Similarity percentage analyzes (SIMPER) were used to estimate the contribution of each species to the difference observed in the composition of seedlings between each collection period. For this analysis, the software Past, version 2. I4, was used (HAMMER et al., 200I).

\section{RESULTS}

\section{Botanical composition of the vegetation in the field}

Forty-eight species, out of 536 emerged seedlings, were identified and distributed into six botanical families. The most representative families were Asteraceae (306 individuals and II species), Poaceae (I44 individuals and 2 I species), Rubiaceae (49 individuals and 3 species), and Cyperaceae ( 16 individuals and 8 species). Among the identified species, the Ageratum fastigiatum (Gardner) (24.44\%), Gamochaeta americana (13.43\%), Melinis minutiflora (I I.75\%), and Achyrocline satureioides ( $8.95 \%$ ) were predominant, being responsible for $58.58 \%$ of the seedlings emerged in the seed bank samplings.

From the information about seeds emerged from different depths, it was possible to visualize the oscillations of the parameters during the evaluation period (Figure 3 ). The tendency of decrease in the diversity of species throughout the storage period was observed (Figure 3d). However, the number of individuals and the relative density (Figure 3a, b) tended to remain stable until the 4th month, with an increase in the density for the collections of higher depths (90-100 and 190-200 cm). Analyzing the Pielou equability (Figure 3c), a decrease of this index was observed, which was higher from the 4th month.

\section{Abundance of seedlings in relation to the stocking period and storage depth in the pile}

It was possible to verify that the species abundance in the three layers studied did not differ significantly from each other $(P>0.05)$ and that the variations occurred were due to chance, however, presenting a significant difference between the collection times of the seed bank $(\mathrm{P}>0.05)$ (Table I). 
TABLE I Permutational multivariate analysis of variance (PERMANOVA), for abundance of seedlings emerged in the seed bank of altitude fields in three depths and four periods in the Poços de Caldas plateau region, MG.

\begin{tabular}{cccccc}
\hline Source & $\mathrm{df}$ & $\mathrm{SS}$ & $\mathrm{MS}$ & Pseudo-F & $\mathrm{P}$ (perm) \\
\hline Period & 3 & 24060 & 8019.9 & 3.04 & 0.00 I* $^{*}$ \\
Depth & 2 & 3949.5 & 1974.8 & 0.74854 & 0.808 \\
Interaction & 6 & 13124 & 2187.4 & 0.82913 & 0.825 \\
Residue & 23 & 60678 & 2638.2 & - & - \\
Total & 34 & $1.01 \times 10^{5}$ & - & - & - \\
\hline
\end{tabular}

df - degree of freedom; SS - sum of squares; MS - mean square; $P$ (perm) permutation of the P-value.

The PERMDISP (Table 2) analyzes provided information on changes in the variability of the communities present in the seed bank that could be used to infer changes in seed bank diversity (GIORIA et al., 2014).

Despite the statistical difference among the sampled periods, the groups were not distinctly separated by the influence of some species common to all groups (Figure 4). The collections performed at time I presented greater similarity, that is, the emerged species resembled among the repetitions; however, over the storage time, greater species dissimilarity occurred (time 4). The greatest dissimilarity, found from the 8th month on, is due to the presence of species only in the initial months of storage (Achyrocline satureioides and Paspalum pilosum), while
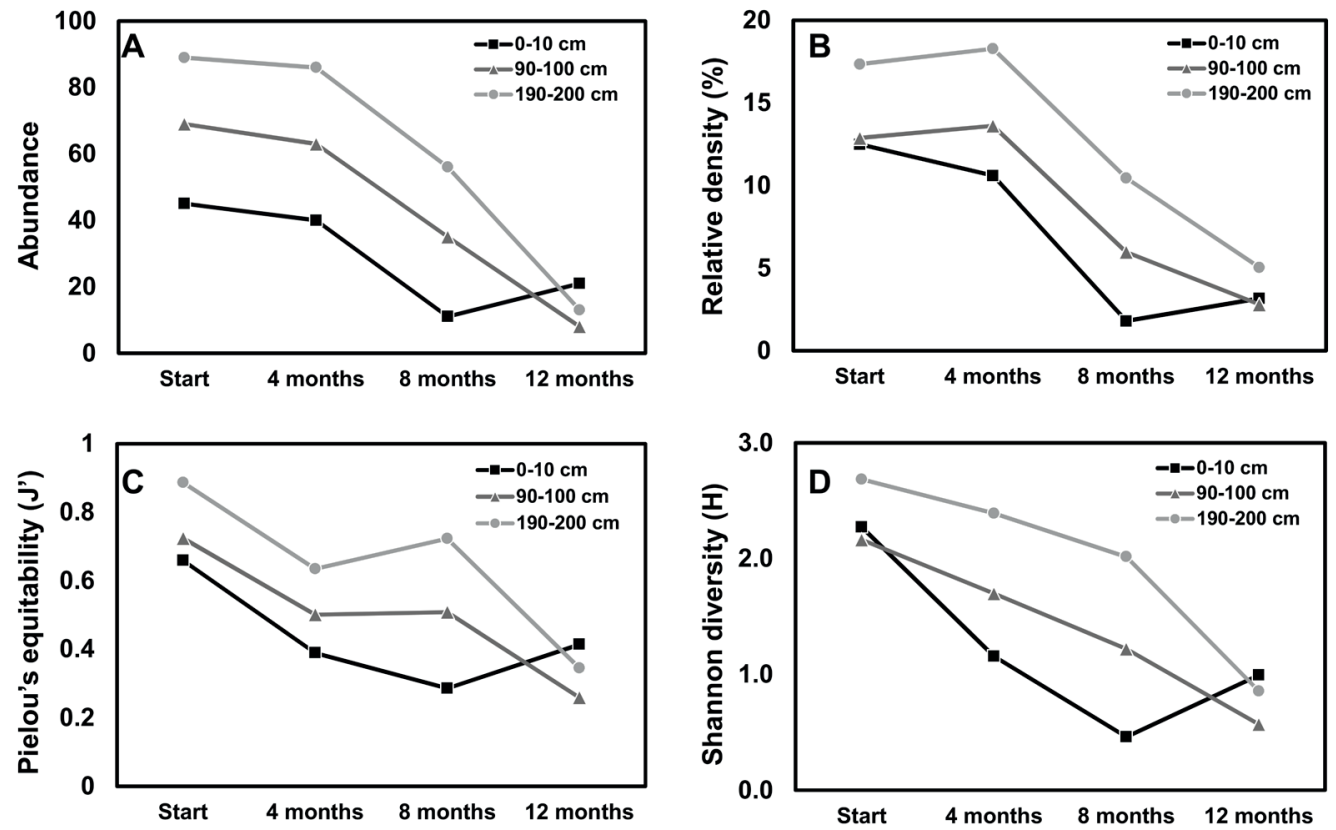

FIGURE 3 Analysis of abundance (A), relative density (B), Pielou's equation (C), and Shannon index (D) of the seed bank in the four collections carried out from November 201 I to November 20I2, at three depths (0 to I0,90 to I00, and I90 to $200 \mathrm{~cm}$ ) of topsoil stocked during the bauxite mining process under altitude fields at three depths and four periods in the Poços de Caldas plateau region, MG. 
TABLE 3 Contributions of the species to the similarities in the collections obtained through the SIMPER routine ( $90 \%$ similarity).

\begin{tabular}{|c|c|c|c|c|c|c|c|c|}
\hline Period & \multicolumn{2}{|c|}{ Start } & \multicolumn{2}{|c|}{4 months } & \multicolumn{2}{|c|}{8 months } & \multicolumn{2}{|c|}{12 months } \\
\hline Average similarity & \multicolumn{2}{|c|}{41.22} & \multicolumn{2}{|c|}{39.83} & \multicolumn{2}{|c|}{24.46} & \multicolumn{2}{|c|}{9.54} \\
\hline Species & AM & $\begin{array}{l}C \\
\%\end{array}$ & AM & $\begin{array}{c}C \\
(\%)\end{array}$ & AM & $\begin{array}{c}\mathrm{C} \\
(\%)\end{array}$ & AM & $\begin{array}{c}C \\
(\%)\end{array}$ \\
\hline Achyrocline satureioides & 0.79 & 6.89 & 1.48 & 17.85 & 0.62 & 4.96 & - & - \\
\hline Ageratum fastigiatum & 2.27 & 37.32 & 1.99 & 32.52 & 1.63 & 43.61 & 0.44 & 35.66 \\
\hline Andropogum bicornis & - & - & - & - & - & - & 0.22 & 8.32 \\
\hline Baccharis dracunculifolia & - & - & - & - & - & - & 0.22 & 5.82 \\
\hline Borreria capitata & 0.49 & 3.47 & - & - & - & - & - & - \\
\hline Borreria latifolia & 0.89 & 7.99 & 0.67 & 9.84 & 0.95 & 37.59 & - & - \\
\hline Cyperus aggregatus & - & - & - & - & - & - & 0.22 & 11.65 \\
\hline Echinolaena inflexa & - & - & 0.49 & 3.91 & - & - & - & - \\
\hline Eragrostis rufescens & - & - & - & - & 0.38 & 4.85 & - & - \\
\hline Gamochaeta americana & 1.68 & 17.13 & 1.14 & 7.67 & - & - & - & - \\
\hline Melinis minutiflora & 1.4 & $|3.8|$ & 1.09 & 9.01 & - & - & 0.38 & 6.16 \\
\hline Panicum pilosum & - & - & - & - & - & - & 0.22 & 6.47 \\
\hline Paspalum pilosum & 0.57 & 4.09 & 0.99 & 12.79 & - & - & - & - \\
\hline Schizachyrium tenerum & - & - & - & - & - & - & 0.44 & 20.61 \\
\hline
\end{tabular}

AM - Average Abundance; C\% - contribution (\%).

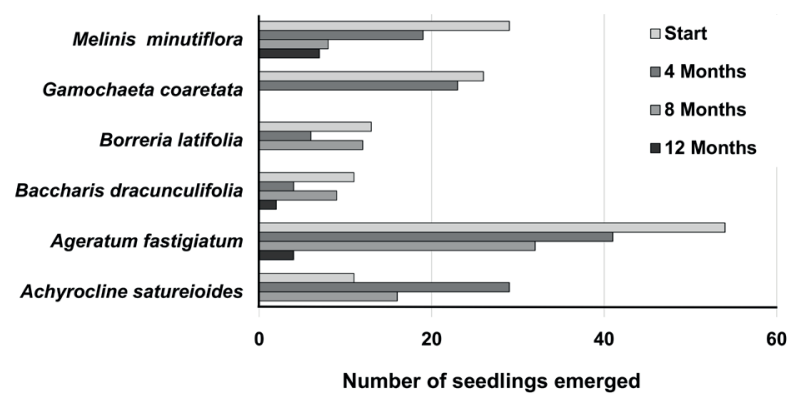

FIGURE 4 Number of seedlings emerged in the seed bank in soils on bauxite in the Poços de Caldas plateau region, MG, by species, in the periods studied.

the species that contributed most to the dissimilarity in the evaluated periods, we highlight Ageratum fastigiatum, which contributed with $23 \%$ to the dissimilarity between the first and last collection. For these same collections, it was noted that six species contributed with $64 \%$ of dissimilarity. Meanwhile, for the species Achyrocline satureisodes, the emergence observed at the beginning of the trial (four months) presented low dissimilarity when compared with the final period analyzed ( 12 months).

\section{DISCUSSION}

\section{Composition of species and influences on soil seed bank}

The seed bank have 44 species distributed into six botanical families, sufficient to make up the initial vegetation. However, it showed low richness when compared with botanical surveys in campos de altitude. Evaluating nine surveys, carried out in different areas of altitude fields in southeastern Brazil, Ribeiro et al. (2007) verified that the number of species in the seed bank varied between 57 and 127 and between 17 and 49 for families.
In this region, the phytosociological survey of the shrubby herbaceous stratum performed by Barros (20I4) showed a Shannon diversity index $\left(\mathrm{H}^{\prime}\right)$ of 3.10, while in the present study, the highest value for the Shannon diversity index of the seeds was 2.68. This lower diversity is due to the smaller extension of the sampling area for the study of the composition of seed banks (VANDVIK et al., 2016). Although it is not possible to make the selection or predict the diversity of species that will make up the seed bank (NORMAN et al., 2006), it is important to consider environmental factors that may affect the emergence of seedlings, such as seed dormancy mechanisms and species phenology.

Environmental conditions can represent chemical and physical filters (e.g. water and nutritional deficiencies), which induce or limit the establishment of some species (GILARDELLI et al., 20I5), making them dominant or rare, able or not to colonize the substrate under the established conditions. Sprengelmeyer and Rebertus (2015) suggest that the determining factors for the presence and/or abundance of plant species in the seed bank are the distance of rock outcrops, soil depth, and altitude. From a different perspective, under storage conditions, seeds of some species are more susceptible to deterioration by the attack of fungi and predators and climatic adversities (SHANGA et al., 2016). The strategy of species propagation, such as number and dispersion of seeds (HORÁČKOVÁ et al., 20I5; SHANGA et al., 2016), seed viability, and vegetative propagation (LE STRADIC et al., 20I5), and dormant seeds (GARCIA et al., 2014) are also conditioning factors for the species abundance in the recovered areas.

The results of the present study suggest the recognition of the importance of the seed bank in the ecological and functional recovery of mined areas. For 
van Etten et al. (20/4) even with low seed density in the soil seed bank, it is still valuable for post-mining restoration purposes, because in addition to seed supplying, it provides soil microorganisms and suitable means for plant germination and growth. Moreover, some devices can be adopted to improve the dispersion and the capacity of the species for their complete establishment and good development (GILARDELLI et al., 20I5). Other complementary interventions, such as planting of seedlings, direct sowing of native plant species, and/or artificial perches, can be considered important to accelerate plant succession (MARTINS, 20I4).

\section{Influence of depth on seed bank storage}

Although, the significant influence was expected at the depths of the stocked pile, the abundance of plant species of the seed bank did not show significant differences at the various depths (Table I). In most soils, seed density decreases rapidly with soil depth (FENNER; THOMPSON, 2005). In soil layers with more than 10 $\mathrm{cm}$, the seed abundance is lower when compared with the more superficial layers (OLIVEIRA et al., 20I5). However, during the stripping process, the layers are mixed and homogenized (in relation to the diversity of propagules), resulting in non-statistical differentiation in the studied depths.

Greater abundance and density were found in the deeper layer (Figures 3a, b). Possibly, in the upper layers, the seeds found favorable conditions and eventually germinated, while the inner ones maintained the seeds in the absence of light and low moisture (RIVERA et al., 2012; OLIVEIRA et al., 20I5). In the 0 to $10 \mathrm{~cm}$ layer, the species abundance was more dispersed than in the inner layers of the stocked pile (PERMIDISP). Although, it is a routine in mining to avoid stocking in stacks of more than $2.00 \mathrm{~m}$ high, the results of this test showed that the lower layers presented smaller losses of viable seeds than the upper layers. However, further studies should be performed comparing such layers under cover conditions, i.e., excluding the influence of light and moisture.

\section{Effect of storage time on the soil seed bank}

Seed bank diversity declined sharply from the fourth month of storage (Figure $3 \mathrm{c}$ ) and from the eighth month, the individuals present were distributed into a few species (Figure 3d). Evaluating seed viability under controlled conditions, Rivera et al. (2012) found that the percentage of seed survival decreased by around $40 \%$ after six months of storage. Thus, in recovery projects, it should be considered that if the topsoil is stocked for more than four months, there may be a significant reduction of plant diversity, as well as the formation of monodominance of some species.

The abundance differed statistically in the sampled times (Table I) and, according to the PERMIDISP analysis (Table 2), it was verified that until the fourth month the abundance was statistically the same, thus determining a period of up to four months for the use of the topsoil in recovery projects. For Salazar et al. (20I I), the seed bank formed in savannas is transient and seasonal, explaining the decreasing viability of the propagules in the bank. These results should not be taken as the unique response of the storage time. Seed bank composition and longevity of species under local conditions (SNYMAN, 2013), besides the interaction between spatial variation and precipitation, may play an important role in the spatial and temporal heterogeneity of seed bank richness and density (SANTOS et al., 20I3).

In areas of Australia, with average annual precipitation around $369.00 \mathrm{~mm}$, the decline in viability of the seed bank was observed only in the second year of storage (GOLOS; DIXON, 20I4). Since the average annual precipitation of the study area is $1,695.00 \mathrm{~mm}$, it is believed that the moisture favors the loss of viability in seed banks in the altitude fields. Thus, as a measure to maximize the viability of the seeds present in the topsoil, it is recommended to adopt adequate measures for the storage of the material with humidity insulation mainly in rainy seasons.

\section{Behavior of seed bank species throughout storage}

The families that contributed the most to dissimilarity were Asteraceae and Poaceae. According to Salazar et al. (20I I), the seed banks of savanna environments have more herbaceous species and very few woody species. However, all species presented a unique pattern of emergence over time. The species that contributed the most to the dissimilarity among the collection times studied were almost always the same, varying only the percentage of specific contribution (Table 3).

Species such as Ageratum fastigiatum, Baccharis dracunculifolia, Echinolaena inflexa, and Melinis minutiflora had individuals emerged at all times, even if the number of emerged individuals was not constant. These may be persistent species of the seed bank or may still present seasonal dormancy (WALCK et al., 2005). The SIMPER analysis also indicates that Melinis minutiflora, an exotic, aggressive, and difficult-to-eradicate species, may become part of the post-recovery community (HOFFMANN; HARIDASSAN, 2008). Therefore, measures must be 
taken to favor the regeneration of native grasses and to prevent its planting of exotic species.

Seeds of the aforementioned species should be better studied, considering mechanisms that suggest their respective longevity. The same can be recommended for others that, even with less abundance, emerged only in the last collection, such as Andropogum bicornis, Cyperus aggregatus, Panicum campestre, Panicum pilosum, and Paspalum plicatulum. As recommended by Gilardelli et al. (2000), in stony soils, ecological recovery must be carried out with species that are able to tolerate a longer period of burial, seasonal dormancy, and germination (WALCK et al., 2005).

\section{CONCLUSION}

Some species were affected by the stockpiling conditions, only emerging in some collections, while others (Achyrocline satureioides, Ageratum fastigiatum, Baccharis dracunculifolia, Borreria capitata, Echinolaena inflexa and Melinis minutiflora) had individuals emerged in all collection periods.

This study points that species in the altitude fields present a differentiated behavior regarding the germination and the temporal patterns of seed dispersion. Such facts may lead to monodominance if the topsoil replenishment exceeds four months of storage.

As a measure to maximize the viability of the seeds present in topsoil, it is recommended to adopt adequate stocking practices of the material, isolating it from excess moisture, especially in rainy seasons.

\section{ACKNOWLEDGMENTS}

Funding and support for this research came from the Fundação de Amparo à Pesquisa do Estado do Amazonas - FAPEAM and the Universidade Federal de Lavras - UFLA.

\section{REFERENCES}

ANDERSON, M.J.; GORLEY, R.N.; CLARKE, K.R. PERMANOVA for PRIMER: guide to software and statistical methods. PRIMER-E Ltd., Plymouth, United Kingdom, 2008, 2I4p.

ANDERSON, M.J. Distance-based tests for homogeneity of multivariate dispersions. Biometrics, v. 62, n. I, p. 245253, 2006.

BARROS, D. A.; GUIMARAES, J. C. C.; PEREIRA, J. A. A.; BORGES, L. A. C.; SILVA, R. A.; PEREIRA, A. A. S. Characterization of the bauxite mining of the Poços de Caldas alkaline massif and its socio-environmental impacts. Revista Escola de Minas, v. 65, n. I, p. I27-133, 2012.
BARROS, D.A. Campos de altitude sob interferência da mineração de bauxita no planalto de Poços de Caldas, MG. 20I4. I43p. PhD thesis. Universidade Federal de Lavras, Lavras-MG.

BASKIN, C.C.; BASKIN, J.M. Seeds: ecology, biogeography and evolution of dormancy and germination. Second edition. San Diego: Elsevier/Academic Press, 2014. 666p.

BORGY, B.; REBOUD, X.; PEYRARD, N; SABBADIN, R; GABA, S. Dynamics of Weeds in the Soil Seed Bank: A Hidden Markov Model to Estimate Life History Traits from Standing Plant Time Series. PLoS ONE, v. 10, n.10, p. I-I5, $20 \mid 5$.

BRASIL. Constituição da República Federativa do Brasil: promulgada em 5 de outubro de 1988. Brasília, DF: Senado, 1988.

CAIAFA, N.A.; SILVA, A.F. Composição florística de um campo de altitude no Parque Estadual da Serra do Brigadeiro, Minas Gerais - Brasil. Rodriguésia, v. 56, n. 87, p. I63-173, 2005.

COSTA, N. de O.; CIELO-FILHO, R.; PASTORE, J.A.; AGUIAR, O.T. de; BAITELLO, J.B.; LIMA, C.R. de; SOUZA, S.C.P.M. de; FRANCO, G.A.D.C. Caracterização florística da vegetação sobre afloramento rochoso na estação experimental de Itapeva, SP, e comparação com áreas de campos rupestres e de altitude. Revista do Instituto Florestal, v. 23, n. I, p. 8I-I08, 201 I.

FENNER, M.; THOMPSON, K. The ecology of seeds. Cambridge University Press, Cambridge, United Kingdom, 2005. 260p.

FERREIRA, C.M.; WALTER, B.M.T.; VIEIRA, D.L.M. Topsoil translocation for Brazilian savanna restoration: propagation of herbs, shrubs, and trees. Restoration Ecology, v. 23, n. 6, p. 723-728, 2015.

GARCIA, Q. S.; OLIVEIRA, P. G.; DUARTE, D. M. Seasonal changes in germination and dormancy of buried seeds of endemic Brazilian Eriocaulaceae. Seed Science Research, v. 24, n. 2 , p. $113-117,2014$.

GILARDELLI, F.; SGORBATI, S.; ARMIRAGLIO, S.; CITTERIO, S.; GENTILI, R. Ecological Filtering and Plant Traits Variation Across Quarry Geomorphological Surfaces: Implication for Restoration. Environmental Management, v. 55, n. 5, p. ||47-I|59, 2015

GIORIA, M.; JAROSÍK, V.; PYSEKA, P. Impact of invasions by alien plants on soil seed bank communities: Emerging patterns. Perspectives in Plant Ecology, Evolution and Systematics, v.16, n, 3. p. I32-142, 2014.

GOLOS, P. J.; DIXON, K. W. Waterproofing topsoil stockpiles minimizes viability decline in the soil seed bank in an arid environment. Restoration Ecology, v. 22, n. 4, p. 495$50 \mathrm{I}, 20 \mathrm{I} 4$. 
HAMMER, Ø.; HARPER, D. A. T.; RYAN, P. D. PAST: Paleontological Statistics Software Package for Education and Data Analysis. Palaeontologia Electronica, v. 4, n. I, p. I-9, 200 I.

HOFFMANN, W. A.; HARIDASSAN, M. The invasive grass, Melinis minutiflora, inhibits tree regeneration in a Neotropical savanna. Austral Ecology, v. 33, n. I, p. 2936, 2008.

HORÁČKOVÁ, M.; ŘEHOUNKOVÁ, K.; PRACH, K. Are seed and dispersal characteristics of plants capable of predicting colonization of post-mining sites? Environmental Science and Pollution Research, v.23, n. 14, p. 13617-13625, 2015.

HU, X.W.; ZHOU, Z.Q.; LI, T.S.; WU, Y. P.; WANG, Y.R. Environmental factors controlling seed germination and seedling recruitment of Stipa bungeanaon the Loess Plateau of northwestern China. Ecological Research, v.28, n.5, p.80I-809, 2013.

IBGE - Instituto Brasileiro de Geografia e Estatística. Manual técnico da vegetação brasileira: sistema fitogeográfico, inventário das formações florestais e campestres, técnicas e manejo de coleções botânicas, procedimentos para mapeamentos. Rio de Janeiro - RJ, 20I2, 27Ip.

LE STRADIC, S.; SILVEIRA, F. A. O.; BUISSON, E.; CAZELLES, K.; CARVALHO, V.; FERNANDES, G.W. Diversity of germination strategies and seed dormancy in herbaceous species of campo rupestre grasslands. Ecological Society of Australia, v. 40, n. 5, p. 537-546, 2015.

MACDONALD, S.E.; LANDHAUSSER, S. M.; SKOUSEN, J.; FRANKLIN, J.; FROUZ, J.; HALL, S.; JACOBS, D. F.; QUIDEAU, S. Forest restoration following surface mining disturbance: challenges and solutions. New Forests, v. 46, n.5-6, p.703-732, 2015.

MAGURRAN, A. Ecological diversity and its measurement. New Jersey: Princeton University, 1988. 175p.

MARTINS, S. V. Recuperação de matas ciliares: no contexto do novo código florestal. 3.Ed. Viçosa: Aprenda fácil editora, 2014. 220p.

MEIRELES, L.D.; KINOSHITA, L.S.; SHEPHERD, G.J. Composição florística da vegetação altimontana do distrito de Monte Verde (Camanducaia, MG), Serra da Mantiqueira Meridional, Sudeste do Brasil. Rodriguésia, v. 65, n.4, p.83I-859. 2014.

MOCOCHINSKI, A. Y.; SCHEER, M. B. Campos de altitude na Serra do Mar paranaense: aspectos florísticos. Floresta, v. 38, n. 4, p. 625-640, 2008.

MORAS FILHO, L. O.; MORAES, R. P.; BARROS, D. A. ; PEREIRA, J. A. A. ; BORGES, L. A. C. Legal Guidelines for Campos de Altitude Restoration. Journal of Sustainable Forestry, v.36, n.3, p.304-307, 2017.
MORAES, F. T.; JIMÉNEZ-RUEDA, J. R. Fisiografia da região do planalto de Poços de Caldas, MG/SP. Revista Brasileira de Geociências, São Paulo, v. 38, n. I, p. 196-208, 2008.

NASCIMENTO, G.O.; PEREIRA, J.A.A.; BARROS, D.A.; FERREIRA, J.B.; OLIVEIRA, S.S. Propagule emergence in topsoil from a high-altitude field and implications for bauxite mining area restoration. International Journal of Biodiversity and Conservation, v. 8, n.II, p. 310319,2016

NORMAN, M.A.; KOCH, J. M.; GRANT, C.D.; MORALD, T.K.; WARD, S; C. Vegetation Succession After Bauxite Mining in Western Australia. Restoration Ecology, v. 14, n. 2, p. 278-288, 2006.

OLIVEIRA-FILHO, A.T. NeoTropTree, Flora arbórea da Região Neotropical: Um banco de dados envolvendo biogeografia, diversidade e conservação. Universidade Federal de Minas Gerais. Available at: http://www.icb. ufmg.br/treeatlan/. Accessed in: 10 Jan 2017.

OLIVEIRA, P. C. de; TOREZAN, J. M. D.; CUNHA, C. N. da. Effects of flooding on the spatial distribution of soil seed and spore banks of native grasslands of the Pantanal wetland. Acta Botanica Brasilica, v. 29, n.3, p. 400-407, 2015

OTT, J.P.; HARTNETT, D.C. Bud-bank and tiller dynamics of co-occurring $\mathrm{C} 3$ caespitose grasses in mixed-grass Prairie. American Journal Of Botany, v. 102, n. 9, p. I-10, 2015.

PAKEMAN, R.J.; SMALL, J.L.; TORVELL, L. Edaphic factors influence the longevity of seeds in the soil. Plant Ecology, v. 213 , n. I, p.57-65, 2012.

PEREIRA, J.A.A.; FONTES, M.A.L. Plano de Manejo do Parque Municipal da Serra de São Domingos. UFLA, v2, 2009, I24p.

RIBEIRO, K.T.; MEDINA, B.M.O.; SCARANO, F.R. Species composition and biogeographic relations of the rock outcrop flora on the high plateau of Itatiaia, SE-Brazil. Brazilian Journal of Botany, v. 30, n.4, p. 623-639, 2007.

RIVERA, D.; JÁUREGUIB, B.M.; PECO, B. The fate of herbaceous seeds during topsoil stockpiling: Restoration potential of seed banks. Ecological Engineering, v. 44, p. $94-101,2012$.

SAFFORD, H. D. Brazilian Paramos I. An introduction to the physical environment and vegetation of the campos de altitude. Journal of Biogeography, v. 26, n. 4, p. 693712, 1999.

SAFFORD, H. D. Brazilian Páramos IV. Phytogeography of the campos de altitude. Journal of Biogeography, v. 17, n. 10, p. I-22, 2007.

SALAZAR, A., GOLDSTEIN, G., FRANCO, A.C.; MIRALLESWILHEL, F. Timing of seed dispersal and dormancy, rather than persistente soil seed-banks, control seedling recruitment of woody plants in Neotropical savannas. Seed Science Research, v. 21, p. 103-1 I6, 201 I. 
SÁNCHEZ, L.E. Mineração: Planejamento para o fechamento prematuro de minas. REM: Revista Escola de Minas, v. 64, n. I, p.II7-I24, 201 I.

SANTOS, D. M. DOS; SILVA, K. A. DA; ALBUQUERQUE, U. P. DE; SANTOS, J. M. F. F. DOS; LOPES, C. G. R.; ARAÚJO, E. DE L. Can spatial variation and inter-annual variation in precipitation explain the seed density and species richness of the germinable soil seed bank in a tropical dry forest in north-eastern Brazil?. Flora, v.208, n.7, p. 445-452, 2013.

SANTOS, D. M.; SANTOS, J. M. F. F.; SILVA, K. A.; ARAÚJO, V. K. R.; ARAÚJO, E. L. Composition, species richness, and density of the germinable seed bank over 4 years in young and mature forests in Brazilian semiarid regions. Journal of Arid Environments, v. 129, p. 93-101, 2016.

SCHEER, M.B.; CURCIO, G.B.; RODERJAN, C.V. Funcionalidades ambientais de solos altomontanos na serra da igreja, Paraná. Revista Brasileira de Ciência do Solo, v. 35, n.4, p. III3-II26, 2011.

SHANGA, Z.; YANGB, S.; WANGC, Y.; SHIC, J.; DINGA, L.; LONGA, R. Soil seed bank and its relation with aboveground vegetation along the degraded gradients of alpine meadow. Ecological Engineering, v.90, p. 268-277, 2016.
SNYMAN, H. A. Disturbances Impact on Longevity of Grass Seeds, Semi-Arid South African Rangeland. Rangeland Ecology \& Management, v. 66, n. 2, p. I43-I56, 2013.

SPRENGELMEYER, E. E.; REBERTUS, A. J. Seed bank dynamics in relation to disturbance and landscape for an ant-dispersed species. Plant Ecology, v.2 I6, n.3, p.37I-38I, 20 I5.

VAN ETTEN, E.J.B.; NEASHAM, B.; DALGLEISH, S. Soil seed banks of fringing salt lake vegetation in arid Western Australia - density, composition and implications for postmine restoration using topsoil. Ecological Management \& Restoration, v. I5, n. 3, p. 239-242, 2014.

VANDVIK, V.; KLANDERUD, K.; MEINERI, E.; MÅREN, I. E.; TÖPPER, J. Seed banks are biodiversity reservoirs: species-area relationships above versus below ground. Oikos, v. I25, n.2, p. 218-228, 2016.

WALCK, J.L., BASKIN, J.M., BASKIN, C.C., HIDAYATI, S.N. Defining transient and persistent seed banks in species with pronounced seasonal dormancy and germination patterns. Seed Science Research, v. 15, n. 3, p.189-196, 2005. 
